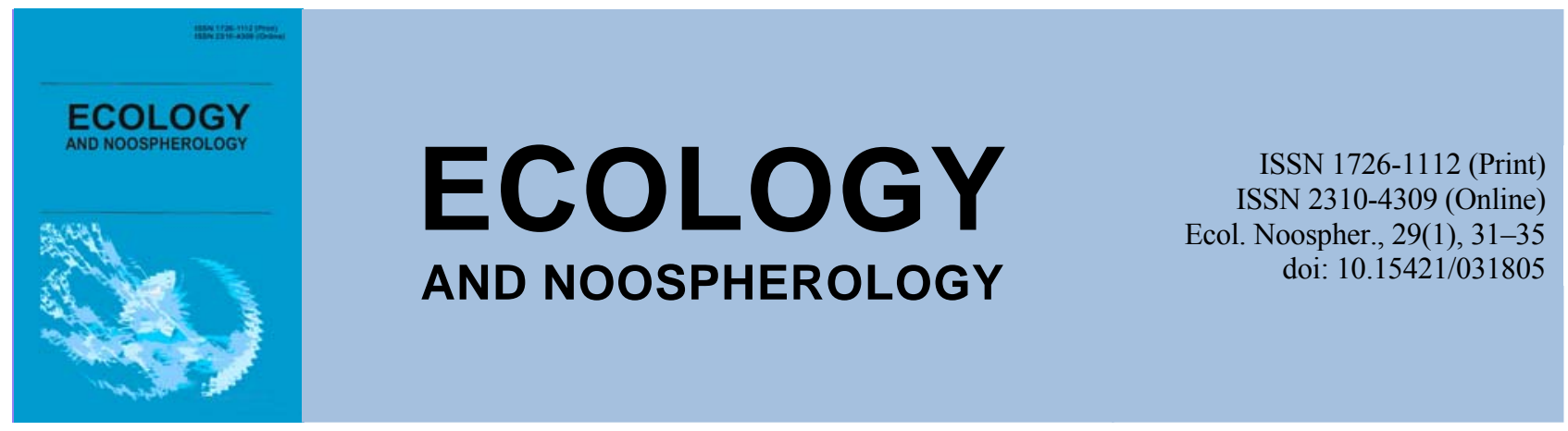

\title{
Syngenesis as a synonym for development process of biogeocenoses: their organization and self-organization
}

\author{
N. V. Voroshylova \\ Dnipro State Agrarian and Economic University, Dnipro, Ukraine
}

Article info

Received 11.02.2018

Received in revised form

20.02.2018

Accepted 27.02.2018

Dnipro State Agrarian and Economic University,

st. S. Efremova, 25, Dnipro,

49600, Ukraine.

Tel.: +38-098-672-38-39

E-mail:Khlyzina@ukr.net
Voroshylova, N. V. (2018). Syngenesis as a synonym for development process of biogeocenoses: their organization and self-organization. Ecology and Noospherology, 29(1), 31-35. doi:10.15421/031805

Syngenesis is leading and determining factor in development of biogeocenoses (Sukachev, 1942) as a phenomenon means its movement over time, and as a process describes its incremental changes toward more or less stable state. Syngenesis is a process of simultaneous formation and development of biogeocenose by living things of all kingdoms of life. We consider the process as: 1) forming, creating (stocking of free land or aquatic areas); 2) a continuous process having indefinite duration, that characterizes constant mobility of composition, structure, and linkages of biogeocenosis; 3) reorganizing process which shows fractures and changes in biogeocenosis structure; 4) recovering, that reflects restoration of general and local disturbances in biogeocenosis, that is as discrete stage-phase processes. Syngenesis is multifactorial grouping process defined by penetration and interaction, cohabitation of living organisms. It is directly related to chaos at various levels and stages of biogeocenosis state and it characterized by different-scale patterns. Statics or kinetics of syngenesis are evidenced in all its forms. Statics reflects certain fixed time points or slowing of movement, and the delay between stages; kinetics should be considered as a process of biogeocenosis motion over time. All syngeneses are subordinated to zonal type of biogeocenosis reproduction and development towards achieving a more or less steady state. All these processes fit together in «organization» category. The organization defines: development of state of being organized; systematic, that is, it embodies the integration and interaction of system-forming factors reflecting development of parts, subsystems, components, elements forming a system sustainability. It is: 1) a constant attribute property of all dynamic systems; 2) a multi-step process for development of any system with a certain level of parallelism on multi-directional and subordinates to general direction of the partial phenomena and processes; 3 ) completeness, simplification, expansion of composition, structure, and linkages; 4) characteristics of changes in total stereostructure of organism community, above-ground and underground layering, occupation of vertical and horizontal spatial niches. The organization determines reorganization of the network interaction system: 1) reconstruction of nature of influences; 2) changes in their power, intensity, concentrations, ranges, and 3) variability in space and time relations, accordingly to biogeocenosis demands. The organization is characterized by follow: 1. Features: 1) discreteness; 2) inequivalence of stages; 3) inequality; 4) different duration; 5) acceleration or deceleration on the background of biogeocenosis demands; 6) slowing as it approaches more or less stable state. 2. Properties: 1) importance; 2) mobility; 3) biogeocenotical conditionality; 4) continuity; 5) equifinality. 3. Functions:1) formation the state of being organized; 2) establishment of structure; 3) development of biogeocenosis; 4) selfdevelopment. Self-organization is one of the characteristic properties of the organization; it is pronounced in biogeocenosis as realization of hidden resources and capabilities by the following phenomena: 1) occurrence of necessary elements qualitatively and quantitatively different in their composition at a certain point of development; 2) elimination of their excessive amounts; 3) preservation of forms adaptive to environment; 4) numerous transitions into latent status for certain elements; their migration (removal) outside of the grouping; 5) modifications: a) taxonomic and ecomorphic spectra; b) changes in polymorphy and size of population; c) total stereostructure of community and its above-ground, subterranean layering; d) occupation of vertical and horizontal spatial niches; e) patchiness and composition; 6) reorganization of the whole network system relationships on the impact. In general, it should be noted that concept on group development and organization is one of broad and insufficiently differentiated in biogeocenology. Self-organization is an objective process of self-moving of biogeocenosis over 
time. It is subject to the same common factors regardless of their orientation to stable or unstable condition in the group. The same factors, phenomena and processes can be both system-forming and system-destroying: interaction of organisms, competition, adaptive response, composition replenishment and depletion, structure complication and simplification, changing in ratios of functional groups.

Keywords: organizing; organization; biogeocenoses; condition; systems; chaos; structure

\title{
Сингенез як синонім розвитку біогеоценозів: їхня організація та самоорганізація
}

\author{
Н. В. Ворошилова
}

Дніпровський державний аграрно-економічний університет, Дніпро, Украйна

У розвитку біогеоценозу провідним і визначним є сингенез як явище, що означає рух його в часі та процес, який характеризує поступальні зміни в напрямку більш або менш стабільного стану. Сингенез є процесом сумісного формування та розвитку біогеоценозу організмами всіх царств живої природи. Кожна стадія сингенезу визначає певний стан біогеоценозу, що змінюється наступним, утворюючи певний ряд або серію. Усі сингенези підпорядковані зональному типу відтворення та розвитку біогеоценозів у напрямку досягнення більш або менш стабільного стану. Кожен біогеоценоз відзначається своєю організованістю та процесами організації, які усталено відображають його просторо-часову нестабільність, що може виражатися невизначено великою множиною картин. Організованість та організація $є$ такими феноменами існування біогеоценозів, які відображають їх певні етапи в динаміці або статику. Організованість $\epsilon$ явищем, а організація - процесом при безлічі забезпечуючих факторів.

\section{Ключові слова: сингенез; організованість; організація; біогеоценоз; стан; система; хаос; структура}

У розвитку біогеоценозу провідним і визначним $\epsilon$ сингенез (Sukachev, 1942) як явище, що означає рух його в часі та процес, який характеризує поступальні зміни в напрямку більш або менш стабільного стану. Сингенез $є$ процесом сумісного формування та розвитку біогеоценозу організмами всіх царств живої природи. Сингенез відображає одну з фундаментальних особливостей життя, пов'язану 3 нестримним його розповсюдженням на поверхні планети, що В. I. Вернадський (Vernadsky, 1926) назвав «розтіканням або натиском» живої речовини.

В одному з аналізів уявлень В. М. Сукачова про сингенез (Kurochkina, Wuhrer, 1987) прослідковані всі його прояви. Проте ми розглядаємо сингенез як такі дискретні стадійнофазові процеси: 1) формуючий, твірний (при заселенні вільних просторів територій або акваторій); 2) неперервний, невизначено тривалий, що характеризує постійну рухомість складу, будови, зв'язків біогеоценозу; 3) перебудовчий, який показує злами, зміни в структурі біогеоценозу; 4) відновлюваний, що відображає відтворення загальних і локальних порушень у біогеоценозі.

Стадії, як вияви крупної членованості сингенезу, порізному визначалися багатьма авторами. В їхніх межах були встановлені фази - ініціальна, оптимальна, термінальна. Як стадії, так і фази є просторово-часово чітко невизначеними, проте для них властивою $€$ збільшення тривалості по мірі наближення біогеоценозу до більш або менш стабільного стану. Природні переходи між стадіями та фазами в них $\epsilon$ розмитими в часі, можливим $\epsilon$ злиття, суміщення термінальної фази попередньої стадії та ініціальної наступної. Таке явище можна, на наш погляд, характеризувати як інтеркінез, екстраполюючи відповідне поняття 3 генетики мейозу (формування гамет). Це є цілком припустимим, подібно використанню в біогеоценології понять ценогенез 3 ембріології, філоценогенез з теорії еволюції, клімакс, менопаузи з фізіології людини.

Кожна стадія сингенезу визначає певний стан біогеоценозу, що змінюється наступним, утворюючи певний ряд або серію. У теорії рослинності для цього вживається поняття «серійні угруповання». Загалом цілком логічно можна визначати серійні біогеоценози в їхньому наближенні до відносної стабільності.
Сингенез $є$ багатозумовленим процесом складання угруповань, визначеним проникненням, взаємодією, зживанням організмів. Він безпосередньо пов'язаний 3 хаосом на різних рівнях і стадіях формування та розвитку біогеоценозів.

Хаос ми розглядаємо як ознаку та властивість сингенезу, що пов'язується з формуванням, неперервним розвитком, мінливістю складу, будови, взаємодій у серійних угрупованнях, змін явищ $\mathrm{i}$ процесів, які їх обумовлюють Фізіономічність, аспективність, монотонність деяких серійних угруповань у певні періоди формуються та існують на основі хаотичного горизонтального розміщення рослин. Від такого розуміння серійних рослинних угруповань як хаотично сформованих утворень слід переходити до розгляду горизонтальної та вертикальної будови тих, які досягають відносної стабілізації (клімаксу) та здатні існувати невизначено тривалий час. Стабільним біогеоценозам також притаманні риси хаосу, що відображають їхню організованість, певні флюктуації чи безпосередньо сукцесії. Разом 3 тим підкреслимо, що хаос особливо чітко, об'єктивно проявляється в умовах природно чи антропно порушених земель, у тому числі на відвалах гірських порід i техногенних штучних субстратах. Хаос серійних угруповань відображається їхніми індивідуальними, еколого-таксономічними спектрами, пояснюється різною розбіжністю, варіабельністю та специфічністю складу, будови та взаємозв'язків. Початкові фази заселення можуть свідчити про широкі можливості «вибору шляху» в умовах високої трофності субстратів, комфортності температурних умов і зволоження для багатьох видів.

Хаос у формуванні складу, будови, взаємодій серійних угруповань на кожному етапі, стадії чи фазі сингенезу може мати різні прояви. Сукцесійні серійні угруповання за своєю суттю $\epsilon$ рядами хаосу, де міра хаотизму зменшується при наближенні до більш стабільного стану. Відзначивши, що сингенез є багатоспрямованим процесом диференційованості біогеоценозу, його перебудов у напрямку стабілізації, зауважимо, що число можливих «виборів» шляхів розвитку зменшується по мірі його «старіння». Розглядаючи проблему хаосу в теорії сингенезу як широкого поняття, що окреслює велику та 
постійну для біогеоценозу сукупність явищ та процесів, значну увагу слід приділити теорії адаптацій. Адаптаціогенез, як і мутагенез, $є$ імовірнісним процесом хаотичної, невизначеної природи. Таким чином, хаос як атрибут сингенезу визначає закономірні явища та процеси розвитку будь-яких біогеоценозів, екосистем і $\epsilon$ необхідною стадією їхніх перетворень і змін. Осмислення та подальша поглиблена розробка цієї проблеми має стати однією з опор теорії рослинних угруповань і біогеоценозів.

Як закономірності сингенезу, що пов'язані з хаосом, на різних етапах розвитку угруповань можна визначити так: 1) сингенез $є$ об'єктивною атрибутивною властивістю життя, що відображає розповсюдження живих організмів на поверхні планети; 2) як процес складання угруповань $\epsilon$ загальним і єдиним для всіх організмів і включає їхні проникнення, взаємодії, зживання; 3) сингенез $\epsilon$ багатоетапним, складним процесом; 4) він відзначається просторово-часовою дискретністю в будь-якій ділянці території чи акваторії; 5) процеси проникнення, вселення, складання, зживання часто упереджено пов'язують 3 уявленням про певний екотопічний добір, конкуренцію, випускаючи 3 поля зору об'єктивність сприятливих взаємодій та взаємовпливів; 6) суміщення екологічних ніш не завжди є конкуренцією та спільне виростання видів може мати характер симбіозу (у широкому розумінні), синергізму, нейтралізму, бути закономірним, а не випадковим; 7) сингенез завершується більш або менш стабільним станом біогеоценозу, проте може тривати неперервно; 8) можливим є утримання в угрупованні екотопічно нестійких видів, у яких така нестійкість компенсується ценотично; 9) різноманітність біогеоценозів, яку здебільшого тлумачать як видову, не $\epsilon$ закономірною та результуючою для стадій відносної стабільності (у багатьох угрупованнях), особливо при різних екстремумах; 10) початкові етапи сингенезу відзначаються більшою видовою складністю, ніж завершальні; 11) монотонність просторової будови, складу та всіх інших особливостей екотопу на початкових фазах і стадіях формування біогеоценозу можуть давати багато варіацій будови, складу, еколого-таксономічних спектрів, його всього та частин унаслідок складних, імовірнісних, невизначено-різноякісних i різнокількісних, хаотичних процесів проникнення організмів у цей екотоп.

У сукцесійному аналізі мають бути враховані всі можливі комбінації видів. Сингенез супроводжується новоутвореннями комбінацій видів і композицій їхнього розташування, що змінюються в процесі їхнього взаємозумовленого існування. Існують критичні межі проникнення та вселення організмів різних видів, за якими починається розлад складу та будови біогеоценозу. Фрагментарна сукцесійність біогеоценозу характеризує неоднозначність сукцесійного руху його частин. Найбільш вразливі компоненти змінюються в розвитку біогеоценозу, також як і рівні їхньої вразливості. У теорії біогеоценології не опрацьованими є геометрія складу, будови, взаємовідносин, розвитку, адаптаціогенезу.

Статика чи кінетика сингенезу проявляються в усіх його формах. Статика відображає певні фіксовані моменти чи сповільнення руху та затримку між стадіями, кінетика ж має розглядатися як процес руху біогеоценозу в часі. Усі сингенези підпорядковані зональному типу відтворення та розвитку біогеоценозів у напрямку досягнення більш або менш стабільного стану.

Розглядаючи сингенез як якісно та кількісно складний, неоднорідний, імовірнісний процес, ми звернули увагу на його суттєву залежність від особливостей проникнення та вселення, котрі виявляються в різних просторово-часових масштабах із суміщенням у рослинних угрупованнях різних життєвих форм і видів різної антропотолерантності. Проникнення рослин у вільні чи заселені рослинами простори зумовлене їхніми походженням, ознаками та властивостями, кількістю діаспор і факторами їхнього занесення, особливостями екологічних умов. Проникнення організмів на вільні площі, в простори чи об'єми територій i акваторій $є$ імовірнісним, хаотичним процесом. Тут хаос як невизначені, неспрямовані рухи, «блукання» організмів та їхніх зачатків, рух біологічно-активних речовин, що визначаються різними складними траєкторіями переміщень, тимчасової чи постійної локалізації, кріплення чи розташування організмів, їхніх органів i зачатків. Проникнення є процесом подолання бар'єрів, насамперед абіотичного характеру. Проникнення через потрапляння тим чи іншим шляхом $\epsilon$ первинним етапом експансії різних видів 3 наступним їхнім розвитком. При відсутності блокуючих факторів відбувається вселення, поширення, заселення будь-якого вільного від рослинності простору чи конкретного біогеоценозу.

Проникнення може бути: 1) одно- та, здебільшого, багатофакторно зумовленим; 2) одно- чи багаторазовим; 3) постійним або періодичним; 4) різнокількісним; 5) рівномірним або нерівномірним. Різні види, залежно від властивих їм екологічних спектрів, можуть захоплювати весь простір або окремі його локуси, утворювати одно- чи полівидові угруповання. Проникнення може блокуватися механічно (рельєфні утворення, водойми, висока рослинність, споруди) чи фізико-хімічними властивостями грунтів i субстратів, особливо їхніми твердістю, щільністю, хімізмом, зволоженням, термічними умовами.

Вселення ми вважаємо таким наслідком проникнення діаспор, який проявляється ростом і розвитком рослин у визначених межах або на всій площі та збереженням їх протягом певного періоду. Виживання характеризує існування та розмноження рослин у просторі проникнення досить тривалий час, а поширення - заселення ними нових просторів і близьких локусів.

Для характеристики складних процесів первинного заселення вільних просторів ми вважаємо доцільним ввести такі поняття: 1) сила проникнення, котра визначається кількістю діаспор на одиницю площі чи об'єму вільного чи заселеного простору; 2) енергія вселення, що характеризує кількість пробуджених до життя діаспор на одиницю площі; 3) швидкість вселення, що $є$ лінійним чи просторовим просуванням одного чи декількох видів на заселених площах за одиницю часу; 4) коефіцієнт виживання оцінюється відношенням кількості існуючих (які збереглися) до кількості пророслих рослин за певний час. Селективну цінність видів ми оцінюємо як енергію вселення та коефіцієнти виживання. Вважаємо окремо виділити основні типи проникнення: 1) фронтальне; 2) мозаїчне; 3) змішане. Типи проникнення, вселення та поширення рослин можуть не збігатися внаслідок різних факторів, які характеризують кожний простір проникнення.

Первинні імовірнісні явища розвитку рослинності, за екотопічного добору видів i форм, змінюються каналізованим формуванням угруповань монотонного характеру чи складних мозаїчних або дифузних профітоценозів, залежно від властивостей проникнення, вселення, приживання рослин (ецезису).

Ецезис є невід'ємною складовою сингенезу. Ецезис (від грецьк. oikisis - колонізація) - процес захоплення організмами (рослинами, тваринами) вільного простору. Досить часто цей термін вживається для позначення імовірнісного складного процесу укорінення, заселення, вторгнення, проникнення, закріплення організмів у вільних чи заселених просторах. Ф. Клементс вважав ецезис однією з чотирьох фаз формування рослинних угруповань, а саме: 1) міграція зачатків рослин на вільний субстрат; 2) проростання та укорінення проростків i, загалом, закріплення мігрантами за собою нового місцевиростання; 3) агрегація чи утворення груп потомства мігрантів навколо материнських особин; 4) інвазія чи укорінення рослин одних груп мігрантів в інші. О. Г. Воронов 
(Voronov, 1963) визначав ецезис як процес пристосування рослин до нових для них умов, який проходить після їхнього проникнення на оголену територію. Це починається $з$ проростання рослин, триває протягом усього періоду росту та закінчується, коли рослини на новому місці репродукують. За Є. М. Лавренком (Lavrenko, 1959), сукцесію визначає ецезис, тобто укорінення тих або інших видів на вільний від рослин ділянці простору. В його трактуванні поняття «ецезис» включає весь процес від моменту інспермації того або іншого виду до його закріплення на ділянці. Рух ецезису не припиняється на цій ділянці й пізніше, аж до формування стабільного угруповання. Б. М. Міркін (Mirkin, 2001) тлумачить ецезис як процес приживання та закріплення рослин при формуванні угруповання. Ецезис, як складова процесу досягнення певної організованості серійних угруповань у різних екотопах, пов'язаний з хаосом, який має субстратну основу та розвивається на фоні імовірнісних, об'єктивних і суб'єктивних, контрольованих і неконтрольованих факторів, умов, процесів проникнення, укорінення, заселення рослинами різних новоутворень.

Здатність до ецезису багатозумовлена та сутнісно залежить від особливостей проникнення, вселення, котрі виявляються в різних просторово-часових масштабах $\mathrm{i}$ суміщенням в біогеоценозах організмів різних життєвих форм. Ецезис $\epsilon$ біорізноманітним i невичерпним. Він визначає рух біогеоценозів за стадіями зонального типу та супроводжується елізіями невідповідних стадій i неадаптованих видів.

Сингенез як один 3 компонентів складного розвитку біогеоценозів у сучасних, об'єктивних умовах забезпечує: 1) їхне становлення; 2) більш або менш реальну їхню зональну стійкість; 3) добір толерантних форм організмів.

Усі ці процеси вписуються в своїй сукупності в категорію «організація». Проте організація (підвищення організованості) та дезорганізація (зниження організованості) є відносними. Руїни будівель 3 точки зору архітектури - це хаос, безпорядок, а з точки зору механіки вони є системами з властивою їм специфічною організованістю. Організація - це: 1) особлива форма зв'язку; 2) процес, націлений на висхідну стадію розвитку системи (Averyanov, 1986); 3) доцільне функціонування чи взаємодії частин системи, що забезпечують iï адаптацію (Yugay, 1985). Її значення полягає в передаванні інформації за допомогою сигналів, які забезпечують доцільну взаємодію елементів живої системи, з наслідками реакцій саморегулювання.

У біогеоценозі організмами різних царств живої природи формуються багатоманітні типи зв'язків. На рівні певних ланок, елементів, осередків і всього угруповання, у процесі розвитку, забезпечується стабільність елементів і зв'язків. Стан біогеоценозу може визначатися організацією та дезорганізацією. Організацію ми розуміємо як процес розвитку та формування структури. Вона в біогеоценозах будь-якого походження характеризує зміни станів за рахунок руху в часі їхніх частин компонентів і онтогенетичних змін організмів як елементів. Організація - це послідовні зміни внутрішніх, системних параметрів на основі об'єктивних, неконтрольованих або контрольованих людиною процесів росту, розвитку та продуктивності у природних біогеоценозах або в антропно-сформованих угрупованнях. Ї̈і організменим аналогом є мобілізація як частковий випадок реакції біосистеми, що належить до організму та виражається в змінах i локальній концентрації елементів, компонентів організму чи у відповідності до характерних природних, якісних взаємодій. Мобілізацію ми розглядаємо як адаптаційний процес перетворення будь-яких систем у період стресу, що відзначається підсиленням певних структур, концентрацією певних функціональних процесів, які забезпечують підвищення стійкості. Мобілізація $\epsilon$ проявом організації та значною мірою характеризує стресовий стан системи.

Організація $є$ неупорядкованим, багатоспрямованим процесом 3 виявом локальних властивостей, мозаїчності екотопу та, зокрема, едатопу, видової та популяційної специфіки біогеоценозів, у тому числі культур- i агробіогеоценозів. В останніх організація виливається в процес активізації, вступу до вегетації потенційно можливих небажаних людині бур'янових рослин на основі ïх зачатків і насіння чи інших організмів.

Організація може розглядатися багатопланово, у різних просторово-часових масштабах. Їй властива просторовочасова асинхронність: 1) на фоні мозаїчності, парцелярності та ярусності вона більш відчутна та помітна; 2) при відносно монотонній вертикальній i горизонтальній будові вона виявляється за рахунок екотонно-серединних відмінностей.

Організація визначає: розвиток організованості, системності, тобто вона втілюе інтеграцію і взаємодії системотвірних факторів, відображаючи розвиток частин, підсистем, компонентів, елементів, які формують сталість систем. Вона є: 1) постійною атрибутивною властивістю всіх динамічних систем; 2) багатоетапним процесом становлення будь-якої системи 3 певним рівнем паралелізму різноспрямованих i підпорядкованих загальному напряму часткових явищ і процесів; 3) ускладненням, спрощенням, розширенням складу, будови, зв'язків; 4) характеристикою змін загальної стереобудови угруповання організмів, надземної та підземної ярусності, освоєння вертикальних і горизонтальних просторових ніш. Організація зумовлює переформування сітьової системи зв'язків: 1) перебудови характеру впливів; 2) змін у їхніх силі, напруженнях, концентраціях, діапазонах; 3) мінливості в просторі та часових зв'язках, відповідно до потреб біогеоценозу.

Сингенез можна розглядати як непереривний процес організації біогеоценозу, який як явище характеризує рухомість структури та формування організованості.

Для організації характерними $є$ :

1. Ознаки: 1) дискретність; 2) нерівнозначність етапів; 3) їхня нерівноправність; 4) різна тривалість; 5) прискорення чи сповільнення на фоні потреб біогеоценозу; 6) сповільнення по мірі наближення до більш або менш стабільного стану.

2. Властивості: 1) значущість; 2) рухомість; 3) біогеоценотична зумовленість; 4) непереривність; 5) еквіфінальність.

3. Функції: 1) формування організованості; 2) становлення структури; 3) розвиток біогеоценозу; 4) саморозвиток.

Однією 3 характерних особливостей організації $\epsilon$ самоорганізація, що виявляється в біогеоценозах як реалізація прихованих ресурсів, можливостей за рахунок таких явищ: 1) появи в їхньому складі необхідних якісно та кількісно різних елементів у певний момент розвитку; 2) усунення їхньої надмірної кількості; 3) збереження адаптивних до середовища форм; 4) багатьох переходів у латентний стан певних елементів, їхньої міграції (винесення) за межі угруповання; 5) змін: а) таксономічних i екоморфічних спектрів; б) змін поліморфності та чисельності популяції; в) загальної стереобудови угруповання та надземної, підземної ярусності; г) освоєння вертикальних i горизонтальних просторових ніш; д) мозаїчності та композицій; 6) переформування сітьової системи зв'язків за характером впливів.

\section{Висновки}

У загальному підсумку відзначимо, що уявлення про розвиток угруповань, про їхню організованість і організацію $\epsilon$ одним 3 осяжних i недостатньо диференційованих в біогеоценології. Самоорганізація є об'єктивним процесом саморухомості біогеоценозу в часі. Вона підпорядкована одним і тим же закономірностям незалежно від їхньої 
спрямованості до стабільного чи нестабільного стану угруповання. Одні і ті ж фактори, явища та процеси можуть бути як системно-твірними, так і системно-руйнівними: взаємовпливи організмів, конкуренція, адаптивне реагування, поповнення та збіднення складу, ускладнення та спрощення будови, зміни співвідношень функціональних груп.

На рівні певних ланок, елементів, осередків і всього біогеоценозу, у процесі розвитку забезпечується стабільність елементів і зв'язків.

Кожний біогеоценоз відзначається своєю організованістю та процесами організації, котрі усталено відображають його просторово-часову нестабільність, яка може виражатися невизначено великою множиною картин.

Дослідження проведені на кафедрі екології та охорони навколиинього середовищза ДДАЕУ у рамках держбюджетної теми Міністерства освіти $i$ науки України «Розробка сучасної концепчії відновлення біотичного потенціалу рекультивованих земель для рачуінального землевикористання» № 0117 U004291.

\section{References}

Averyanov, A. N. (1986). Sistemnoe ponimanie mira [Systemic understanding of the world]. Moscow.(in Russian).
Kurochkina, L. Ya., Vuhrer, V. V. (1987). Razvitie idey V. N. Sukacheva o singeneze [Development of V. N. Sukachev's ideas on syngenesis]. Issues of biogeocenosis dynamics. International scientific and practical conference devoted to the memory of academician V. N. Sukachev. Nauka, Moscow, 5-27 (in Russian).

Lavrenko, E. M. (1959). Osnovnye zakonomernosti rastitel'nyh: soobshchestv i puti ih izucheniya [Basic conformities to law vegetable: associations and way of their study]. The field geobotany, 1. Academy of science of USSR, Moscow-Leningrad, 13-75 (in Russian).

Mirkin, B. M. (2001). Tolkovyy slovar sovremennoy fitotsenologii [Modern explanatory dictionary fytocoenology]. Nauka, Moscow (in Russian).

Sukachev, V. N. (1942). Ideya razvitiya v fitotsenologii [The idea of development in phytocenology]. Soviet botanist, 5-17 (in Russian).

Vernadsky, V. I. (1926). Biosfera [Biosphere]. Hoshymyzdat, Leningrad (in Russian).

Voronov, A. G. (1963). Geobotanika [Geobotany]. Moscow (in Russian)

Yugay, G. A. (1985). Obschaya teoriya zhizni [General theory of life]. Moscow (in Russian). 